\title{
Wpływ modutu porodowego na stan emocjonalny matki, tworzenie więzi z dzieckiem i stan neurobehawioralny noworodka*
}

\author{
The influence of birth modus on the emotional state of the mother, bonding, \\ and the newborn's neurobehavioural state
}

\author{
Dorota Pilch \\ Zakład Pielęgniarstwa Pomorskiego Uniwersytetu Medycznego w Szczecinie \\ ul. Żołnierska 48, 71-210 Szczecin \\ Kierownik: dr hab. n. zdr., prof. PUM Elżbieta Grochans
}

\section{SUMMARY}

Introduction: Childbirth is an important event, both in a woman's, and in her family's lives, an event which carries a huge emotional charge and influences the functioning of a triad.

Labour is a physiological process which may have health (somatic, psychological, mental) and economic consequences. Irrespective of the reasons why it is performed, caesarean section involves surgical, obstetric and anaesthesiological intervention, as well as the necessity for pharmacological agents.

Bonding between parents and their children serves as a basis for optimal psychomotor development, and the first year is important for the rest of life.

The aim of the study was to assess the influence of the labour mode on the mother's emotional state, mother-child bonding, and the infant's neurobehavioural state.

Material and methods: The plan of this study was approved by the Bioethical Commission of the Pomeranian Medical University in Szczecin (BN-001/108/08). The research material comprised 200 women and their children. The following instruments were used in this study: an original questionnaire, the Edinburgh Postnatal Depression Scale (EPDS), the Mother-Child Relationship FIRST score (MCR FIRST score), the Brazelton Scale, also known as the Neonatal Behavioural Assessment Scale (NBAS). The umbilical blood was used to determine the level of cortisol as a stress marker.

Statistical analysis was performed using the Shapiro-Wilk test, the $\chi^{2}$ test, the Mann-Whitney U-test, the Fisher test, and the Spearman rank correlation coefficient. The accepted significance level (p) was equal to 0.05 (the acceptable type I error).

Results: Around $35 \%$ of the women took part in prenatal education, and $59 \%$ of them declared the intention to participate in postnatal education. The respondents wanted someone close to be with them during delivery (65.5\%), although only $35 \%$ had such a possibility. Women giving birth naturally were more often accompanied by their partners $(\mathrm{p}=0.00005)$. Less than half of the women $(35 \%)$ had skin-to-skin contact with their babies, and there was a difference between delivery mode $(p=0.01)$. Attempts at breastfeeding were made by $81.5 \%$ of those surveyed. Women after c-section less often tried to breastfeed their babies than their counterparts after natural delivery $(p=0.003)$. The levels of cortisol in umbilical blood were significantly higher after natural labour than after caesarean section ( $<<0.00001)$.

The assessment of the risk of postnatal depression performed with the EPDS did not demonstrate significant differences between women in particular delivery modes $(p=0.82)$. The percentage of 'crying' children was similar in both modes $(12 \%$ of naturally born babies and $13 \%$ of those born by c-section); the difference was not statistically significant $(p=1.0)$.

Infant examination with the Brazelton Scale revealed differences in babies' behaviour in 30 parameters of the scale in favour of naturally born children. Children born through caesarean section had rarer contact with their mothers after delivery $(\mathrm{p}=0.01)$.

Conclusions: Naturally born babies obtained higher scores on the NBAS, which is an argument for the promotion of this delivery mode. Naturally born babies had significantly higher cortisol levels and more frequent direct contact with their mothers after delivery, which creates favourable conditions for forming bonds. Delivery mode had no influence on the occurrence of postpartum depression, according to the EPDS ( $p=0.82$ ).

Key words: delivery mode, postpartum depression, newborn neurobehavioural status, cortisol, bonding.

\section{STRESZCZENIE}

Wstęp: Poród jest wydarzeniem zarówno w życiu kobiety, jak i całej rodziny, niosącym duży ładunek emocjonalny wpływający na funkcjonowanie triady. Poród to proces fizjologiczny, który może pociągnąć za sobą skutki zdrowotne (somatyczne, psychologiczne, psychiczne) i ekonomiczne. Cięcie cesarskie, niezależnie od powodów, z jakich zostało przeprowadzone, wiąże się z interwencjami o charakterze chirurgicznym, położniczym i anestezjologicznym oraz potrzebą stosowania środków farmakologicznych. Więzi między rodzicami a dzieckiem stanowią bazę do optymalnego rozwoju psychomotorycznego, a pierwszy rok życia potomka jest ważny w świetle jego całego życia.

*Zwięzła wersja rozprawy doktorskiej przyjętej przez Radę Wydziału Nauk o Zdrowiu Pomorskiego Uniwersytetu Medycznego w Szczecinie. Promotor: prof. dr hab. n. med.Jacek Rudnicki. Oryginał obejmuje: 153 strony, 28 tabel, 25 rycin, 148 pozycji piśmiennictwa. 
Celem badań była ocena wpływu modułu porodowego na stan emocjonalny matki, tworzenie więzi z dzieckiem i stan neurobehawioralny noworodka.

Materiał i metody: Projekt badań został zatwierdzony przez Komisję Bioetyczną Pomorskiego Uniwersytetu Medycznego w Szczecinie (BN-001/108/08). Materiał badawczy stanowiło 200 kobiet i ich dzieci. W pracy wykorzystano autorski kwestionariusz ankiety oraz Edinburgh Postnatal Depression Scale (EPDS), Mother-Child Relationship FIRST score (MCR FIRST), skalę Brazeltona (Neonatal Behavioral Assessment Scale - NBAS). Krew pępowinowa służyła oznaczeniu poziomu kortyzolu jako markera stresu.

W analizie statystycznej użyto testu Shapiro-Wilka, $\chi^{2}$, U Manna-Whitneya, Fishera oraz korelacji rang Spearmana. Poziom istotności testu (p) ustalono jako 0,05 (dopuszczalny błąd pierwszego rodzaju).

Wyniki: Badane uczestniczyły w edukacji przedporodowej (35\%), a 59\% z nich deklarowała chęć uczestnictwa w edukacji poporodowej. Kobiety chciały odbyć poród z bliską osobą $(65,5 \%)$ ale taką możliwość miało tylko 35\% kobiet. Obecność partnera życiowego przy porodzie częściej występowała w module fizjologicznym ( $p=0,00005)$. Kontakt cielesny z dzieckiem typu skóra do skóry miało 35\% kobiet i różniło to kobiety między modułami porodowymi $(p=0,01)$. Częstość podejmowania karmienia piersią wśród badanych wynosiła $81,5 \%$. Kobiety rodzące za pomocą cięcia cesarskiego rzadziej podejmowały karmienie piersią niż rodzące fizjologicznie ( $p=0,003)$. Poziom kortyzolu uzyskany z krwi pępowinowej noworodków po porodzie fizjologicznym był wyższy niż po cięciu cesarskim ( $\mathrm{p}<0,00001)$.

Ocena zagrożenia depresją poporodową matek wg EPDS nie wykazała istotnych statystycznie różnic między badanymi kobietami w poszczególnych modułach porodowych $(p=0,82)$.

W obu modułach porodowych występował podobny odsetek dzieci „krzyczących” (12\% urodzonych fizjologicznie i 13\% za pomocą cięcia cesarskiego), co nie stanowiło różnic między noworodkami $(\mathrm{p}=1,0)$.

Ocena noworodków skalą Brazeltona pozwoliła na zaobserwowanie różnic w zachowaniu dzieci w 30 parametrach skali na korzyść dzieci urodzonych fizjologicznie. Matki rozwiązywane cięciem cesarskim rzadziej miały kontakt z dziećmi po porodzie $(\mathrm{p}=0,01)$.

Wnioski: Noworodki urodzone fizjologicznie uzyskały lepsze wyniki w ocenie NBAS, co pozwala na promowanie tego modułu porodowego. Poziom kortyzolu był istotnie wyższy u dzieci urodzonych fizjologicznie, a matki częściej miały bezpośredni kontakt z dzieckiem po porodzie, co sprzyjało tworzeniu więzi. Moduł porodowy nie wpływał na występowanie depresji poporodowej wg EPDS $(p=0,82)$.

Słowa kluczowe: moduł porodowy, depresja poporodowa, stan neurobehawioralny noworodka, kortyzol, więzi.

\section{WSTEP}

Poród jest zjawiskiem fizjologicznym, a przyjście na świat dziecka należy do ważnych wydarzeń rodzinnych, społecznych. Z porodem wiążą się następstwa zdrowotne (somatyczne, psychologiczne, psychiczne) i ekonomiczne. Psychologiczne następstwa poporodowe mogące wystąpić u matki to dysforyczny syndrom (popłakiwanie, baby blues), depresja i psychoza poporodowa $[1,2,3,4]$. Zaburzenia te warunkują czynniki psychiczne, hormonalne, socjalne, kulturowe. Znaczący wpływ na wystąpienie zaburzeń mogą mieć interakcje międzyludzkie, w tym partnerskie. Cięcie cesarskie, niezależnie od powodów, z jakich zostało przeprowadzone, wiąże się z interwencjami o charakterze chirurgicznym, położniczym i anestezjologicznym oraz potrzebą stosowania środków farmakologicznych [5, 6]. Nie można wykluczyć potencjalnego ryzyka epidemiologicznego związanego z przeprowadzaniem znieczulenia i operacji [6]. Kobieta ciężarna zaliczana jest do grupy zwiększonego ryzyka powikłań anestezjologicznych wynikających z samej fizjologii ciąży. Najczęstszą przyczyną hipoksji podczas porodu operacyjnego jest blokada współczulna w wyniku podania leków znieczulenia regionalnego, szczególnie wyraźnie i częściej obserwowana podczas znieczulenia podpajęczynówkowego oraz zespół aortalno-kawalny w wyniku leżenia rodzącej na plecach $[5,6,7,8]$. Środki anestetyczne podawane matce podczas znieczulenia w mniejszym lub większym stopniu mogą docierać do płodu. Doświadczenie znieczulającego, wybór metody znieczulenia, dobór leków - to czynniki, które posiadają bezpośredni wpływ na stan urodzeniowy dziecka $[6,8]$. Znajomość zagadnień związanych z wpływem sposobu rozwiązania ciąży na powstawanie więzi dziecko-matka (rodzice) ma kluczowe znaczenie w opiece nad kobietą w okresie porodu i połogu, ponieważ pozwala na zaplanowanie opieki położniczej oraz anestezjologicznej z uwzględnieniem elementów mających bezpośredni wpływ na relacje między matką i dzieckiem, a także satysfakcję matki z porodu $[6,8,9,10,11]$. Podnoszenie się wartości stężenia kortyzolu w krwi płodu pomaga narządom wewnętrznym (płucom, wątrobie, żołądkowi, nerkom) przygotować się do życia poza organizmem matki. Kortyzol jest odpowiedzialny zarówno za ostatnie stadia dojrzewania dziecka płodowego, jak i bierze udział w inicjacji procesu porodu, a wzrastanie jego poziomu jest gwarancją wydalenia dziecka płodowego w optymalnym momencie dojrzałości fizjologicznej [12]. Tworzenie więzi to proces wieloaspektowy, w którym brak problemów (zawodowych, prawnych), satysfakcja seksualna, stabilizacja finansowa, dojrzałość emocjonalna partnerów odgrywają ważną rolę.

Wyposażenie percepcyjne noworodka ukierunkowane jest na kontakt społeczny przede wszystkim z matką, rodzicami $[13,14,15,16,17]$. Umiejętność odczytywania zachowania dziecka jest pomocna rodzicom i pozwala na wspieranie słabszych obszarów jego funkcjonowania, a tym samym stymulowanie jego rozwoju. Rodzice lepiej rozumiejący swoje dziecko, chętniej się z nim komunikują, jakość kontaktu jest wyższa, co sprzyja tworzeniu więzi typu bezpiecznego [15, 18, 19, 20]. Karmienie piersią sprzyja tworzeniu więzi, będąc naturalnym przedłużeniem prenatalnych relacji z matką po narodzinach [19].

Celem badań była ocena wpływu modułu porodowego na stan emocjonalny matki, tworzenie więzi z dzieckiem i stan neurobehawioralny noworodka. Cele szczegółowe dotyczyły: 
a) porównania stanu emocjonalnego kobiet po przebytym porodzie fizjologicznym i po cięciu cesarskim,

b) porównania poziomu kortyzolu jako wykładnika stresu w obu modułach porodowych,

c) wskazania różnic pod względem neurobehawioralnym między dziećmi urodzonymi w sposób fizjologiczny i przez cięcie cesarskie.

\section{MATERIA I METODY}

Projekt badań uzyskał pozytywną opinię Komisji Bioetycznej Pomorskiego Uniwersytetu Medycznego w Szczecinie (PUM) nr BN-001/108/08. Badania przeprowadzono w Klinice Położnictwa i Klinice Patologii Noworodka PUM w Samodzielnym Publicznym Szpitalu Klinicznym nr 2 (SPSK nr 2). Badaniem objęto 200 kobiet $(n=200)$ i ich dzieci $(n=200)$. W badaniu do oceny stanu emocjonalnego matek zastosowano Edynburską Skalę Depresji Poporodowej - Edinburgh Postnatal Depression Scale - EPDS (prawidłowy stan emocjonalny cechuje się wynikiem poniżej $10 \mathrm{pkt}$ ). Skalą Mother Child Relationship FIRST (MCR FIRST) oceniano postawy matek w opiece nad dzieckiem. Stan neurobehawioralny noworodków oceniano w 2.-3. dobie życia dziecka skalą Brazeltona (Neonatal Behawioral Assesssment Scale - NBAS).

Po porodzie pobierano $2 \mathrm{~mL}$ krwi z tętnicy pępowinowej do oznaczenia stężenia kortyzolu, następnie po oznaczeniu próbki przekazywano ją do laboratorium hormonalnego PUM w SPSK nr 2, gdzie krew była odwirowywana i zamrożona. Kortyzol oznaczano w Laboratorium Centralnym SPSK nr 1 (ISO 9000).

Autorski kwestionariusz ankiety zawierał pytania dotyczące opinii badanych na temat znaczenia sposobu narodzin dla matki i dziecka.

Analiza statystyczna dotyczyła oceny liczebności i częstości względnej (\%) występowania danej cechy. Test ShapiroWilka zastosowano do oceny zgodności rozkładu zmiennych ciągłych z rozkładem normalnym. Zdecydowana większość zmiennych wykazywała rozkłady istotnie odbiegające od normalnego, dlatego do analizy zastosowano testy nieparametryczne. Porównania pomiędzy grupami dokonano, stosując test U Manna-Whitneya oraz dokładny dwustronny test Fishera. Korelacje między zmiennymi analizowano, obliczając współczynnik korelacji rang Spearmana.

Poziom istotności testu (p) ustalono jako równy 0,05 (dopuszczalny błąd pierwszego rodzaju). Dla wartości p < 0,05 ustalono, że różnica lub korelacja była istotna statystycznie.

\section{WYNIKI}

Spośród badanych kobiet 92 urodziły dzieci naturalnie (46\%), a 108 przez cięcie cesarskie (54\%). Najmłodsza z badanych miała 17 lat, najstarsza 41 (Me 29 lat). Wiek urodzeniowy dzieci mieścił się między 36. a 41. tygodniem życia płodowego (Me 39 Hbd). Masa dzieci kształtowała się 2400-4720 g (Me 3225 g).
Kobiety pozostawały w związkach, jedynie 3,5\% było samotnych. Połowa badanych kobiet była pierworódkami (50\%), drugie dziecko urodziło 41\%, a najmniej było wieloródek posiadających troje i więcej dzieci (9\%). Wykształcenie wyższe posiadało $45 \%$ badanych, średnie $33,5 \%$. Prawie $80 \%$ badanych mieszkało w mieście, nieliczne kobiety na wsi $(4,5 \%)$.

Uzyskane wyniki badań świadczą, że badane cenią obecność bliskiej osoby przy porodzie (65,5\%). Jedynie 35\% spośród rodzących posiadało przy sobie osobę towarzyszącą (partnera życiowego) podczas porodu. Kobietom rodzącym fizjologicznie istotnie częściej towarzyszył partner życiowy niż w przypadku cięcia cesarskiego ( $\mathrm{p}=0,00005)$.

Sposób narodzin dziecka był istotny dla 43,5\% matek. Ponad połowa kobiet uznała, że sposób narodzin jest ważny również dla dziecka $(60,5 \%)$. Badane uczestniczyły w edukacji przedporodowej $(35,5 \%)$ i chciały wziąć udział w edukacji poporodowej (59\%), która była im proponowana na oddziale położniczym w ramach realizacji programu edukacji poporodowej. Kontaktu z dzieckiem trwającego powyżej 2 minut nie doświadczyło po porodzie $26,1 \%$ rodzących fizjologicznie i 42,6\% kobiet, których poród zakończył się cięciem cesarskim. Kobiety rodzące fizjologicznie istotnie częściej miały kontakt z dzieckiem po porodzie niż w przypadku cięcia cesarskiego $(\mathrm{p}=0,01)$. Karmienie piersią podjęło po porodzie $81,5 \%$ położnic. Zaobserwowano statystycznie istotne różnice między podejmowaniem karmienia piersią a modułem porodowym na korzyść karmienia piersią ( $\mathrm{p}<0,00001)$ - tabela 1.

Nie wykazano istotnych różnic w występowaniu zagrożenia depresją poporodową w skali EPDS $(\mathrm{p}=0,82)$. Mediana punktacji dla rodzących fizjologicznie wynosiła 5 pkt, dla rozwiązanych cięciem cesarskim 6 pkt, co mieściło się w zakresie wyniku prawidłowego (tab. 2).

Poziom kortyzolu różnił noworodki; po porodzie fizjologicznym obserwowano istotnie wyższe stężenie kortyzolu w krwi pępowinowej ( $\mathrm{p}<0,00001)$ - tabela 3 .

Ocena NBAS noworodków w zakresie odruchów noworodkowych i reakcji wywołanych mieściła się w zakresie normy w obu modułach; nie wykazano różnic między modułami. Zaobserwowano natomiast różnice wysoce istotne statystycznie między noworodkami urodzonymi w obu modułach porodowych; w obszarze habituacji - dzieci urodzone cięciem cesarskim szybciej ignorowały stymulację wizualną $(\mathrm{p}<0,00001)$ i stymulację bodźcami ożywionymi (kontakt z osobą badającą) oraz nieożywionymi (przedmiotami do stymulacji wzrokowej i słuchowej), a także w ocenie czujności w ramach obszaru interakcji społecznych wykazano różnice między noworodkami świadczące o lepszej reaktywności na bodźce ożywione i nieożywione noworodków urodzonych fizjologicznie ( $p<0,0001)$. Wykazano również różnice w dojrzałości ruchowej noworodków urodzonych fizjologicznie a pozostałymi dziećmi $(\mathrm{p}<0,00001)$. W zakresie dojrzałości ruchowej oraz reakcji obronnych istotnie częściej różniły się noworodki urodzone drogami natury $(\mathrm{p}<0,00001)$. Noworodki urodzone fizjologicznie były częściej lepiej zorganizowane i prezentowały dojrzalsze odruchy obronne ( $\mathrm{p}=0,01)$, były mniej drażliwe i wykazywały większą trwałość stanów $(p<0,001)$. 
TABELA 1. Charakterystyka badanej grupy (test U Manna-Whitneya)

\begin{tabular}{|c|c|c|c|c|c|c|c|c|}
\hline \multirow{3}{*}{ Parametr } & \multicolumn{6}{|c|}{ Modut porodowy } & \multirow{3}{*}{ z } & \multirow{3}{*}{$\mathbf{p}$} \\
\hline & \multicolumn{3}{|c|}{$\begin{array}{c}\text { fizjologiczny } \\
n=92\end{array}$} & \multicolumn{3}{|c|}{$\begin{array}{c}\text { cięcie cesarskie } \\
n=108\end{array}$} & & \\
\hline & średnia & Me & SD & średnia & $\mathrm{Me}$ & SD & & \\
\hline Wiek matek & 28,96 & 30 & 5,21 & 30,12 & 29 & 5,45 & $-1,14$ & 0,25 \\
\hline Wykształcenie matek & 2,23 & 2 & 0,77 & 2,23 & 2 & 0,79 & 0,02 & 0,98 \\
\hline Status ekonomiczny matek & 2,09 & 2 & 0,63 & 2,06 & 2 & 0,77 & 0,45 & 0,65 \\
\hline Warunki mieszkaniowe & 2,08 & 2 & 0,70 & 1,96 & 2 & 0,66 & 1,09 & 0,28 \\
\hline Miejsce zamieszkania & 2,78 & 3 & 0,46 & 2,72 & 3 & 0,57 & 0,30 & 0,66 \\
\hline Praca zarobkowa & 2,18 & 2 & 0,72 & 2,17 & 2 & 0,80 & 0,16 & 0,85 \\
\hline Wiek dzieci (Hbd) & 39,45 & 39 & 3,07 & 39 & 39 & 1,40 & 1,82 & 0,05 \\
\hline Masa dziecka (g) & 3411,7 & 3325 & 469,8 & 3465,9 & 3495 & 661,3 & $-0,93$ & 0,34 \\
\hline Liczba posiadanych dzieci & 1,52 & 1 & 0,46 & 1,7 & 2 & 0,79 & $-1,51$ & 0,09 \\
\hline
\end{tabular}

n - liczba badanych; Me - mediana; SD - odchylenie standardowe; z - wyniki testu U Manna-Whitneya; $p$ - poziom istotności Kodowanie:

Wykształcenie podstawowe i zawodowe: o; średnie: 1; wyższe: 2.

Status ekonomiczny bardzo dobry: 1; dobry: 2; zadowalajacy: 3; niezadowalajacy: 4.

Warunki mieszkaniowe bardzo dobre: 1; dobre: 2, zadowalające: 3; niezadowalające: 4

Miejsce zamieszkania na wsi: 1; w miasteczku: 2; w mieście: 3.

Praca zarobkowa bardzo dobra: 1; dobra: 2; zadowalająca: 3; niezadowalająca: 4; bycie bezrobotną: 5 .

TABELA 2. Wyniki testu U Manna-Whitneya dla Edynburskiej Skali Depresji Poporodowej (EPDS) w poszczególnych modułach porodowych

\begin{tabular}{|c|c|c|c|c|c|c|c|c|}
\hline \multirow{3}{*}{ Parametr } & \multicolumn{6}{|c|}{ Modut porodowy } & \multirow{3}{*}{ z } & \multirow{3}{*}{$p$} \\
\hline & \multicolumn{3}{|c|}{$\begin{array}{c}\text { fizjologiczny } \\
n=92\end{array}$} & \multicolumn{3}{|c|}{$\begin{array}{c}\text { cięcie cesarskie } \\
n=108\end{array}$} & & \\
\hline & średnia & $\mathrm{Me}$ & SD & średnia & Me & SD & & \\
\hline EPDS & 5,55 & 5 & 3,07 & 5,7 & 6 & 3,40 & $-0,21$ & 0,82 \\
\hline
\end{tabular}

n - liczba badanych; Me - mediana; SD - odchylenie standardowe; z - wynik testu U Manna-Whitneya; p - poziom istotności

TABELA 3. Modut porodowy a poziom stężenia kortyzolu w krwi pępowinowej

\begin{tabular}{lcccccc} 
& \multicolumn{4}{c}{ Poziom kortyzolu } & & \\
\cline { 2 - 4 } Modut porodowy & $\begin{array}{c}\text { niski } \\
\%\end{array}$ & $\begin{array}{c}\text { norma } \\
\%\end{array}$ & $\begin{array}{c}\text { wysoki } \\
\%\end{array}$ & $\chi^{2}$ & p \\
\hline Poród naturalny & 3,3 & 22,8 & 73,9 & $\begin{array}{c}82,45 \\
\text { df }=2\end{array}$ & $<0,00001$ \\
\hline Cięcie cesarskie & 20,4 & 70,5 & 11,1 & & \\
\hline
\end{tabular}

Dzieci w obu modułach różniły się istotnie pod względem przytulności $(\mathrm{p}<0,0001)$. Porównanie umiejętności uspokajania się w odpowiedzi na manewry badającego, jak i próby samouspokajania się noworodków nie różniły noworodków w poszczególnych modułach $(\mathrm{p}=0,34)$.

Występowanie reakcji ze strony autonomicznego układu nerwowego na stres nie odbiegało od normy i nie różniło istotnie statystycznie noworodków w obu modułach porodowych. Dzieci urodzone naturalnie istotnie częściej się uśmiechały $(\mathrm{p}=0,0003)$.

Punktacja dodatkowa stanowi jakościowe podsumowanie, uchwycenie subtelnych oznak stresu. Sposób regulacji stanów istotnie różnicował badane noworodki $(p=0,016)$ - tabela 4 .

Zachowanie dzieci w poszczególnych modułach porodowych przedstawiono w tabeli 5. Ilość spokojnych, jak i krzyczących dzieci była podobna, a różnica nie była istotna statystycznie $(\mathrm{p}=1,0)$.

W tabeli 6 przedstawiono rozkład wyników skali FIRST wśród badanych matek. Kobiety, które urodziły dzieci fizjologicznie, w ocenie karmienia piersią częściej uzyskiwały optymalny wynik (2), na co wskazuje średnia - Śr = 1,7; Me = 2. Wynik ten różnił istotnie statystycznie matki rodzące fizjologicznie od rozwiązanych cięciem cesarskim $(p<0,0001)$.

Kontakt matki z dzieckiem wg skali FIRST w zakresie mówienia, sposobu patrzenia na nie różnił istotnie statystycznie matki po porodzie fizjologicznym od rodzących cięciem cesarskim. Matki rodzące siłami natury były bardziej zaangażowane w opiekę $(\mathrm{p}=0,02)$ - tabela 7 .

\section{DYSKUSJA}

Zagadnienia przedstawione w niniejszej pracy obejmują tworzenie więzi matki z dzieckiem, jej stan emocjonalny oraz zachowanie noworodka w poszczególnych modułach porodowych. Kobiety badane przez Hubera i Seelbach-Goebela pierwsze dziecko urodziły przez cięcie cesarskie zaplanowane na życzenie [21]. Wszystkie z nich uczestniczyły w planowej, przedporodowej rozmowie edukacyjnej na temat możliwości rodzenia w sposób naturalny po uprzednim cięciu cesarskim. Po porodzie badane odpowiadały na otwarte pytania kwestionariusza dotyczące satysfakcji z wybranego modułu porodowego oraz bondingu. Interesujące jest, że 44,4\% wybierających poród naturalny miało wrażenie, że decyzja nie była akceptowana przez otoczenie. Wszystkie rodzące naturalnie $(100 \%)$ były zadowolone zarówno z wybranego modułu, jak 
TABELA 4. Stan neurobehawioralny dzieci a moduł porodowy

\begin{tabular}{|c|c|c|c|c|c|c|c|c|c|c|}
\hline \multirow{3}{*}{ Parametr } & \multicolumn{8}{|c|}{ Modut porodowy } & \multirow{3}{*}{ z } & \multirow{3}{*}{$\mathrm{p}$} \\
\hline & \multicolumn{4}{|c|}{ fizjologiczny } & \multicolumn{4}{|c|}{ cięcie cesarskie } & & \\
\hline & n & Śr & Me & SD & $\mathrm{n}$ & Śr & Me & SD & & \\
\hline \multicolumn{11}{|c|}{ Habituacja } \\
\hline Wygaszanie reakcji na światło & 65 & 6,66 & 7 & 1,68 & 93 & 6,01 & 6 & 1,88 & 2,29 & 0,02 \\
\hline Wygaszanie reakcji na grzechotkę & 63 & 5,82 & 6 & 1,67 & 93 & 5,7 & 6 & 2,01 & $-0,14$ & 0,88 \\
\hline Wygaszanie reakcji na dzwonek & 62 & 6,08 & 7 & 1,91 & 89 & 6,22 & 7 & 1,71 & $-0,40$ & 0,68 \\
\hline Wygaszanie reakcji na stymulację stopy & 63 & 6,44 & 7 & 1,99 & 82 & 6,03 & 6 & 2,1 & 1,12 & 0,26 \\
\hline \multicolumn{11}{|c|}{ Interaktywne bodźce społeczne } \\
\hline Ożywione bodźce wzrokowe & 92 & 4,29 & 4 & 1,66 & 101 & 2,99 & 3 & 1,3 & 5,66 & $<0,00001$ \\
\hline Ożywione bodźce wzrokowo-słuchowe & 92 & 5,13 & 5 & 1,61 & 101 & 3,61 & 3 & 1,46 & 6,11 & $<0,00001$ \\
\hline Nieożywione bodźce wzrokowe & 92 & 4,28 & 5 & 1,97 & 104 & 3,36 & 3 & 1,45 & 5,39 & $<0,00001$ \\
\hline Nieożywione bodźce wzrokowo-słuchowe & 92 & 5,5 & 6 & 1,87 & 104 & 4 & 4 & 1,49 & 5,69 & $<0,00001$ \\
\hline Nieożywione bodźce słuchowe & 91 & 5,71 & 6 & 1,86 & 104 & 4,23 & 4 & 1,45 & 5,91 & $<0,00001$ \\
\hline Ożywione bodźce słuchowe & 92 & 6,13 & 6 & 1,6 & 108 & 4,97 & 5 & 1,44 & 5,33 & $<0,00001$ \\
\hline Czujność & 92 & 5,65 & 6 & 1,39 & 108 & 4,02 & 5 & 1,18 & 5,27 & $<0,00001$ \\
\hline \multicolumn{11}{|c|}{ Układ ruchowy } \\
\hline Ogólne napięcie mięśniowe & 92 & 5 & 5 & 0,79 & 108 & 4,98 & 5 & 0,5 & $-0,50$ & 0,61 \\
\hline Dojrzałość ruchowa & 92 & 5,33 & 5 & 1,35 & 108 & 4,62 & 4 & 1,13 & 4,37 & $<0,00001$ \\
\hline Podciąganie do siedzenia & 92 & 3,69 & 3 & 1,77 & 108 & 3,56 & 3 & 1,75 & 0,68 & 0,49 \\
\hline Odruchy obronne & 92 & 5,72 & 7 & 2,26 & 108 & 5,17 & 5 & 1,88 & 2,48 & 0,01 \\
\hline Aktywność & 92 & 4,46 & 5 & 0,93 & 108 & 4,42 & 4 & 0,86 & 0,82 & 0,41 \\
\hline \multicolumn{11}{|c|}{ Organizacja stanów } \\
\hline Szczyt zainteresowania & 92 & 4,7 & 5 & 0,94 & 108 & 4,66 & 4,5 & 0,98 & 0,61 & 0,53 \\
\hline Prędkość pobudzania & 92 & 4,14 & 4 & 1,68 & 108 & 4,28 & 4 & 1,74 & 0,09 & 0,92 \\
\hline Pobudliwość/drażliwość & 92 & 3,3 & 3 & 1,24 & 107 & 3,82 & 4 & 1,25 & $-3,39$ & 0,001 \\
\hline Trwałość stanów & 92 & 3,17 & 3 & 1,07 & 107 & 3,46 & 3 & 0,87 & $-2,68$ & 0,01 \\
\hline \multicolumn{11}{|c|}{ Regulacja stanów } \\
\hline Przytulność & 92 & 5,97 & 4 & 1,3 & 108 & 5,24 & 5,5 & 1,28 & 4,30 & $<0,00001$ \\
\hline Umiejętność uspokajania się & 90 & 5,46 & 6 & 1,35 & 108 & 5,28 & 6 & 1,33 & 0,66 & 0,5 \\
\hline Samouspokajanie się & 92 & 3,61 & 3 & 1,45 & 108 & 3,48 & 3 & 1,54 & 0,94 & 0,34 \\
\hline Wkładanie rąk do buzi & 92 & 4,15 & 3 & 1,71 & 108 & 3,25 & 3 & 1,86 & 3,67 & 0,0002 \\
\hline \multicolumn{11}{|c|}{ Układ autonomiczny } \\
\hline Drżenia & 92 & 2,14 & 1 & 2,08 & 108 & 1,83 & 1 & 1,62 & 0,26 & 0,79 \\
\hline Wzdryganie & 92 & 1,77 & 2 & 0,91 & 108 & 1,89 & 2 & 0,97 & $-0,84$ & 0,4 \\
\hline Zmienność zabarwienia skóry & 92 & 4,68 & 5 & 0,82 & 108 & 4,79 & 5 & 0,9 & $-1,17$ & 0,24 \\
\hline \multicolumn{11}{|c|}{ Uśmiechy } \\
\hline Liczba uśmiechów & 92 & 2,1 & 2 & 1,73 & 108 & 1,25 & 1 & 1,29 & 3,67 & 0,0003 \\
\hline \multicolumn{11}{|c|}{ Punktacja dodatkowa } \\
\hline Jakość czujności & 92 & 5,92 & 6 & 1,35 & 108 & 4,94 & 5 & 1,54 & 4,80 & $<0,00001$ \\
\hline Koszt skupienia uwagi & 92 & 6,17 & 6 & 1,19 & 108 & 5,37 & 6 & 1,32 & 4,25 & $<0,00001$ \\
\hline Pomoc ze strony badającej & 92 & 6,48 & 7 & 1,06 & 108 & 5,75 & 6 & 1,01 & 4,78 & $<0,00001$ \\
\hline Ogólna nerwowość & 92 & 6,81 & 7 & 1,46 & 108 & 5,94 & 6 & 1,62 & 4,06 & $<0,00001$ \\
\hline Odporność/wytrzymałość & 92 & 6,2 & 6 & 1,14 & 108 & 5,64 & 6 & 1,2 & 3,48 & 0,0008 \\
\hline Regulacja stanów & 92 & 6 & 6 & 1,08 & 108 & 5,64 & 6 & 1,1 & 2,39 & 0,02 \\
\hline Emocjonalna ocena badającego & 92 & 7,02 & 7 & 1,25 & 108 & 6,19 & 6 & 1,33 & 4,70 & $<0,00001$ \\
\hline
\end{tabular}

n - liczba badanych; Śr - średnia; Me - mediana; SD - odchylenie standardowe; z - wyniki testu U Manna-Whitneya; p - poziom istotności 
i relacji z dzieckiem oraz z tego, że sprostały urodzeniu dziecka. Jedynie 6,9\% spośród kobiet po cięciu cesarskim odczuwało zadowolenie w związku z przebytym cięciem cesarskim [21]. Odczuwanie obcości wobec dziecka miało miejsce częściej po cięciach cesarskich (38,7\%). Autorzy podkreślają konieczność edukowania kobiet i podnoszenia kwestii fizycznego obciążenia w następstwie cięcia cesarskiego, o możliwym psychicznym wpływie na okres poporodowy [21]. Badania Skoczylasa i Bińczyckiej-Anholcer pokazały, że przebieg porodu rodzących fizjologicznie po przebytym cięciu nie różnił się istotnie statystycznie pod względem położniczym. Nie zaobserwowano również różnic w stanie urodzeniowym dzieci. Autorzy uważają, że próba porodu drogami natury po przebytym cięciu może obniżyć znacząco liczbę zabiegów operacyjnych i związanych z tym powikłań [22]. W badaniach własnych tylko część kobiet (35,5\%) brała udział w edukacji przedporodowej, gdzie mogłyby zostać przedstawione aspekty położnicze, anestezjologiczne oraz emocjonalne w poszczególnych modułach porodowych w odniesieniu do matki i dziecka. Część kobiet miała świadomość znaczenia sposobu narodzin dla zdrowia

TABELA 5. Zachowanie dzieci w poszczególnych modutach porodowych (dokładny dwustronny test Fishera)

\begin{tabular}{|c|c|c|c|c|}
\hline \multicolumn{4}{|c|}{ Modut porodowy } & \multirow{3}{*}{$p$} \\
\hline \multicolumn{2}{|c|}{$\begin{array}{l}\text { fizjologiczny } \\
n=92\end{array}$} & \multicolumn{2}{|c|}{$\begin{array}{c}\text { cięcie cesarskie } \\
n=108\end{array}$} & \\
\hline $\begin{array}{l}\text { dziecko } \\
\text { spokojne }\end{array}$ & $\begin{array}{c}\text { dziecko } \\
\text { krzyczące }\end{array}$ & $\begin{array}{l}\text { dziecko } \\
\text { spokojne }\end{array}$ & $\begin{array}{c}\text { dziecko } \\
\text { krzyczące }\end{array}$ & \\
\hline $81(88,04 \%)$ & $11(11,96 \%)$ & $94(87,04 \%)$ & $14(12,96 \%)$ & 1,0 \\
\hline
\end{tabular}

$\mathrm{n}$ - liczba badanych; $\mathrm{p}$ - poziom istotności

TABELA 6. Rozkład wyników skali FIRST wśród badanych matek

\begin{tabular}{lccc}
\multicolumn{1}{c}{ Parametr skali FIRST } & $\begin{array}{c}\text { Stabe } \\
(\%)\end{array}$ & $\begin{array}{c}\text { Średnie } \\
(\%)\end{array}$ & $\begin{array}{c}\text { Optymalne } \\
(\%)\end{array}$ \\
\hline Feeding (karmienie) & 1,5 & 45,5 & 53 \\
\hline Interested (zainteresowanie) & 0,5 & 15 & 84,5 \\
\hline Response (reagowanie) & 0,5 & 29,5 & 70 \\
\hline $\begin{array}{l}\text { Speech (mówienie lub } \\
\text { kontakt wzrokowy) }\end{array}$ & 3,5 & 61,5 & 35 \\
\hline Touch (dotykanie) & 2 & 52 & 46 \\
\hline
\end{tabular}

Karmienie na poziomie słabym: 0; na średnim 1; na optymalnym 2.

Zachowanie matki w stosunku do dziecka wpływające na budowanie więzi: postawy słabo budujące więź: o; dobry poziom: 1; optymalny: 2 . matki i dla dziecka (odpowiednio 43,5\% i 60,5\% badanych), co warto wykorzystać w pracy edukacyjnej.

Psycholodzy wskazują na powtarzalność zachowań w zakresie opieki nad dzieckiem. Jeśli więzi między matką a dzieckiem nie zostaną zapoczątkowane w szpitalu, czyli w optymalnym dla obydwojga momencie, przypuszcza się, że kontakt ten będzie trudniejszy w okresie późniejszym [13, 15]. Wczesny kontakt, szczególnie cielesny (skóra do skóry), wiąże się z oddziaływaniem hormonów takich jak oksytocyna, prolaktyna, katecholaminy oraz uwalnianiem endorfin, dzięki którym łatwiej obydwojgu redukować stres i trudy porodu [23]. Postawy mężczyzn wobec ciąży i narodzin dziecka ustawicznie zmieniają się, a dokonująca się ewolucja oraz wzrost zaangażowania mężczyzn mają emocjonalne konsekwencje w triadzie. Przeprowadzone przez Ribero badania wskazały, że wspieranie matki dziecka podczas porodu i we wczesnym okresie życia dziecka dodatnio wpływa na relacje w triadzie matka-ojciec-dziecko [24].

Ponad połowa badanych kobiet $(65,5 \%)$ stwierdziła, że obecność bliskiej osoby podczas porodu jest dla nich ważna. Ich intencją było odbycie porodu z osobą bliską, ale tylko połowa rodzących fizjologicznie i $22,2 \%$ rozwiązanych cięciem cesarskim kobiet zrealizowało ten zamiar. Standard socjalny szpitali polskich często uniemożliwia przebywanie dodatkowych osób w salach poza pacjentem i niezbędnym personelem medycznym. $\mathrm{W}$ badanym materiale $35 \%$ kobiet nie miało kontaktu z dzieckiem po porodzie. Rowe-Murray i Fisher zbadali jakość pierwszego kontaktu skalą FCI (First Contact Index) oraz stan emocjonalny matki skalą EPDS we wczesnym okresie poporodowym, uzyskując następujące wyniki: kobiety m.in. po porodzie naturalnym otrzymały wyższe wartości indeksu FCI, następnie te, które urodziły spontanicznie, ale w sposób zabiegowy i najniższy wynik posiadały rodzące przez cięcie cesarskie [25]. Wyższa jakość kontaktu z dzieckiem mierzona FCI była w szpitalu przyjaznym dziecku niż innych biorących udział w badaniu placówkach. Różnice w jakości pierwszego kontaktu matki z dzieckiem były znaczące statystycznie i negatywnie korelowały z obiema skalami (EPDS; POMS) [25]. Prawdopodobnie polskie realia wpłynęły na fakt, że kontakt w diadzie różnił się istotnie statystycznie w zależności od modułu porodowego i częściej występował po porodzie fizjologicznym. Natomiast nie zaobserwowano różnic istotnych statystycznie między kobietami w obu modułach a wynikami skali EPDS.

TABELA 7. Wyniki testu U Manna-Whitneya dla wyników skali FIRST i modułu porodowego

\begin{tabular}{|c|c|c|c|c|c|c|c|c|}
\hline \multirow{3}{*}{ Parametr } & \multicolumn{6}{|c|}{ Modut porodowy } & \multirow{3}{*}{$\mathbf{z}$} & \multirow{3}{*}{$\mathrm{p}$} \\
\hline & \multicolumn{3}{|c|}{$\begin{array}{l}\text { fizjologiczny } \\
n=92\end{array}$} & \multicolumn{3}{|c|}{$\begin{array}{l}\text { cięcie cesarskie } \\
n=108\end{array}$} & & \\
\hline & Śr & Me & SD & Śr & Me & SD & & \\
\hline Feeding (karmienie) & 1,70 & 2 & 0,48 & 1,35 & 1 & 0,51 & 4,83 & $<0,00001$ \\
\hline Interested (zainteresowanie) & 1,81 & 2 & 0,41 & 1,86 & 2 & 0,34 & $-0,70$ & 0,47 \\
\hline Response (reagowanie) & 1,75 & 2 & 0,43 & 1,64 & 2 & 0,49 & 1,45 & 0,14 \\
\hline $\begin{array}{l}\text { Speech (mówienie lub kontakt } \\
\text { wzrokowy) }\end{array}$ & 1,41 & 1 & 0,51 & 1,23 & 1 & 0,54 & 2,30 & 0,02 \\
\hline Touch (dotykanie) & 1,48 & 1 & 0,50 & 1,39 & 1 & 0,56 & 1,01 & 0,30 \\
\hline
\end{tabular}

n - liczba badanych; Śr - średnia; Me - mediana; SD - odchylenie standardowe; z - wyniki testu U Manna-Whitneya; p - poziom istotności 
W przypadku cięć cesarskich kontakt matki z dzieckiem miał niekiedy miejsce, jednak był zbyt krótki i nie odpowiadał przyjętym założeniom czasowym oraz jego formie. Wynik ten można zmienić, poprawiając organizację sali operacyjnej oraz zastępując często niemożliwy kontakt dziecka z matką na kontakt z ojcem [26]. Wyniki wczesnego kontaktu ojca z dzieckiem przedstawił Erlandsson [27]. Dzieci po cięciu cesarskim były otoczone tradycyjną formą opieki zapewnionej przez szpital oraz związanej z wczesnym kontaktem skóra-skóra prowadzonym zastępczo przez ojca dziecka przez pierwsze 2 godz. po porodzie. Dzieci z „grupy ojców” sprawujących opiekę mniej płakały niż dzieci otoczone tradycyjną opieką, a różnica była wysoce istotna statystycznie. Dzieci te wykazywały także wcześniej chęć ssania piersi. Różnica między aktywnością dzieci ocenianą skalą NBAS była bardzo istotna statystycznie na korzyść tych, które posiadały ojców jako opiekunów w tym czasie [27].

Wartości kortyzolu uzyskane z krwi pępowinowej w badaniu własnym wskazują na istotne różnice między modułami. W pracy nie uwzględniono obecności i czasu trwania czynności skurczowej, czy odpłynięcia wód płodowych jako czynnika inicjującego rozpoczęcie porodu, co mogłoby prawdopodobnie wytłumaczyć obecność prawidłowych wartości kortyzolu. Niewątpliwie jedynie 11,1\% spośród 108 kobiet rodzących przez cięcie cesarskie miało tylko wysoki poziom kortyzolu, a poziom niski 3\% z grupy 92 rodzących spontanicznie.

Nie wykazano różnic w poziomie depresji poporodowej między modułami porodowymi. Wydawałoby się, że możliwość wystąpienia powikłań podczas operacji czy w okresie pooperacyjnym może być czynnikiem stresogennym dla matek, a także fakt, że wynika z zagrożenia zdrowia i życia dziecka. Operacja położnicza, jaką jest cięcie cesarskie, szczególnie planowa, daje również kobietom nadzieję na rozwiązanie problemu medycznego i stabilizację sytuacji, bezpieczeństwo. Niektóre kobiety ciężarne domagają się wręcz cięcia cesarskiego, co stanowi problem medyczno-etyczny dla systemu ochrony zdrowia [28, 29, 30, 31, 32].

Niederhofer stwierdził, że procesy fizjologiczne są integralne z emocjonalnymi, a ich intensyfikacja, regulacja, wydaje się być związana z regulacją afektywną. Zachowania te podlegają również regulacji fizjologicznej i należą do konsekwencji relacji między fizjologiczną reaktywnością, procesami poznawczych oraz socjalnymi interakcjami [33].

Oceniany przez Niederhofera poziom kortyzolu uzyskany ze śliny dzieci oraz inne wykładniki stresu dziecięcego, jak np. płacz, częstość tętna, były analizowane w aspekcie możliwości regulowania zachowań dziecka przez opiekuna. Do oceny stanu noworodka zastosowano skalę Brazeltona. Stwierdzono, że interakcje społeczne są determinantami temperamentu i służą regulacji emocji w 1. r.ż., stanowiąc rodzicielską „lustrzaną" regulację powodującą rozwój własnej wewnętrznej wrażliwości z jednej strony i ochronę więzi z drugiej [33].

Badanie Rowe-Murray i Fisher dostarczyło informacji na temat karmienia piersią w zależności od sposobu znieczulenia do cięcia cesarskiego. Obie grupy kobiet były identyczne pod względem wieku, rodzicielstwa, kursu przygotowawczego do karmienia piersią. Różniły się natomiast znacząco wyższą częstością i długością okresu karmienia na korzyść znieczulanych przewodowo do cięcia cesarskiego [34].

Dzieci matek, które doświadczyły ok. 30 min kontaktu skóra do skóry po porodzie były dłużej karmione wyłącznie piersią i później odstawiane od piersi [35,36]. Rocha, autor pracy na temat tworzenia więzi w zależności od modułu porodowego w warunkach opieki typu rooming-in, dokonał obserwacji zachowań w ciągu pierwszych 24 godz. po porodzie. Obserwację prowadziła odpowiedzialna osoba z zespołu pielęgniarskiego (nursing care). We wnioskach stwierdzono, że środowisko może wpływać zarówno na zadowolenie matek, jak i ich powodzenie w karmieniu piersią. Rocha podkreśla, że matki po cięciu cesarskim potrzebują więcej uwagi w okresie poporodowym [37].

\section{WNIOSKI}

Po analizie wyników wysunięto następujące wnioski:

1. Moduł porodowy wiązał się z występowaniem istotnych różnic między dziećmi urodzonymi fizjologicznie i przez cięcie cesarskie w zakresie stężenia kortyzolu z krwi pępowinowej $(\mathrm{p}<0,00001)$.

2. Noworodki urodzone fizjologicznie istotnie częściej prezentowały dojrzalsze zachowania adaptacyjne do warunków pozałonowych mierzonych skalą NBAS ( $\mathrm{p}<0,0001)$, stąd potrzeba edukowania przyszłych rodziców w tym zakresie i promowania porodu naturalnego.

3. Noworodki urodzone cięciem cesarskim mogą wymagać podejmowania interwencji o charakterze uspokajającym, stymulacji bodźcami wzrokowymi i słuchowymi (ożywionymi lub nieożywionymi) ze strony rodziców i personelu medycznego.

4. Należy umożliwiać kobietom bezpośredni i długotrwały kontakt z dzieckiem po porodzie, ponieważ kobiety po cięciu cesarskim znacznie istotnie rzadziej go miały $(p=0,01)$, a ich partnerzy byli mniej aktywni w opiece nad dzieckiem i jego matką.

5. Moduł porodowy nie wpływał na występowanie depresji poporodowej wg EPDS ( $p=0,82)$.

\section{PIŚMIENNICTWO}

1. Bielawska-Batorowicz E.: Psychologiczne aspekty prokreacji. Wyd. Nauk. Śląsk, Katowice 2005.

2. Banasiak-Parzych B.: Depresja poporodowa. Przyczyny, skutki, zapobieganie. Wyd. Koldruk, Warszawa 2007.

3. Anestezjologia w położnictwie i medycynie perinatalnej. Zasady i praktyka. Eds: K.M. Kuczkowski, L. Drobnik. Wyd. Med-Media, Warszawa 2009.

4. Łoś Z.: Rozwój psychiczny człowieka w ciągu całego życia. Wyd. Uniw. Wrocław., Wrocław 2010

5. Cohen S., Woods W.: The role of epidural morphine in the post cesarean patient: efficacy and effects on bonding. Anesthesiology. 1983, 58, 500-504.

6. Patel R., Murphy D., Peters T.: Operative delivery and postnatal depression: a cohort study. Br Med J. 2005, 330, 879-882.

7. Charles C.: Cesarskie cięcie. In: Prowadzenie porodu. Eds: V. Chapman, C. Charles. Wyd. Lek. PZWL, Warszawa 2011. 
8. Kuczyńska A.: Sposób na bliski związek. Zachowania wiążące w procesie kształtowania się i utrzymywania więzi w bliskich związkach. Wyd. Instytutu Psychologii PAN, Warszawa 1998.

9. Löbner I.: Warum sind die Frauen heute unsicherer im Umgang mit Geburt und erstem Kind? Die Hebamme. 2008, 21, 45-49.

10. Maciarz A.: Macierzyństwo w kontekście zmian społecznych. Wyd. Akadem. Żak, Warszawa 2004.

11. Tietz A., Zietlow A., Reck C.: Maternal bonding in mothers with postpartum anxiety disorder: the crucial role of subclinical depressive symptoms and maternal avoidance behaviour. Arch Womens Ment Health. Springer-Verlag, Wien 2014

12. Mack S.: Hormone bei Geburt - aktueller Wissensstand. Die Hebamme. 2010, 23, 243-247.

13. Bowlby J.: Przywiązanie. Wyd. Nauk. PWN, Warszawa 2007.

14. Brazelton T.B.: Touchpoints: Your child's emotional and behavioral development. A Merloyd Lawrence Book.

15. Psychologiczne portrety człowieka. Praktyczna psychologia rozwojowa. Ed. A. Brzezińska. Gdańskie Wyd. Psychologiczne, Gdańsk 2005.

16. Lütje W.: Welche Faktoren beeinflussen die Zufriedenheit und das Erleben in der Geburtshilfe? Die Hebamme. 2007, 20, 44-51.

17. Schaper A., Rooney B., Kay N., Silva P.: Use of the Edinburgh Postnatal Depression Scale to identify postpartum depression in a clinical setting. J Reprod Med. 1994, 8 (39), 620-624.

18. Czub T.: Wiek niemowlęcy. Jak rozpoznać ryzyko i jak pomagać? In: Psychologiczne portrety człowieka. Praktyczna psychologia rozwojowa. Ed. A. Brzezińska. Gdańskie Wyd. Psychologiczne, Gdańsk 2005.

19. Langer M.: Psychische Aspekte der Sectio caesarea. Gynaekol Geburtsh Rundsch. 1992, 32, Suppl. 1, 70-71.

20. Oberndörfer K:: Angst im Zusammenhang mit Schwangerschaft und Geburt. Die Hebamme. 2005, 18, 75-78.

21. Huber G., Seelbach-Goebel B.: Re-Sectio versus Spontangeburt nach Sectio: Unterschiede im Erleben von Geburt und Bonding. Die Hebamme. 2006, 19, 227-230.

22. Skoczylas P., Bińczycka-Anholcer M.: Poród drogami natury po przebytym cięciu cesarskim - istotny problem społeczny. Prz Ginek Położ. 2005 5 (3), 161-166.
23. Korte J., Siegmund R.: Beeinflusst der Geburtsmodus die Entwicklung der Tagesrhytmik von Neugeborenen? Die Hebamme. 2004, 17, 161-163.

24. Ribero A.F: At last dyad becomes triad? An evolution of the concept of father and his participation during birth of child. Servir. 2005, 53 (4), 190-194.

25. Rowe-Murray H., Fisher J.: Operative intervention in delivery is associated with compromised early mother-infant interaction. Br J Obstet Gynaecol. 2001, 108 (10), 1068-1075.

26. Jenkner G.: Das Konzept der integrativen, ganzheitlichen Wochenbettpflege. Die Schwester, der Pfleger. Bibliomed Verlag, Melsungen 2003, 10, 362-366.

27. Erlandsson K.: Skin-to-skin care with the father cesarean birth and its effect on newborn crying and prefeeding behavior. Birth. 2007, 34 (2), 105-114.

28. David M.: Sectio auf Wunsch? - Eine kritische Analyse der steigenden Sectiorate aus frauenärztlicher Sicht. Die Hebamme. 2006, 19, 231-235.

29. Hochhausen A.: Die Wunschsectio aus ethischer Sicht. Die Hebamme. 2010 23, 183-187.

30. $M u ß K$ K.: Karmienie piersią - poradnictwo i promocja. MedPharm Polska, Warszawa 2008

31. Suchocki S., Piec P., Łuszczyńska A.: Cięcie cesarskie na życzenie - trudny problem medyczny, etyczny i prawny. Ginek Położ. 2007, 1 (3), 55-62.

32. Wörlein F., Reulbach U., Goecke T.: Erhöhte Rate an Depressionen nach Wunschsectio? Die Hebamme. 2006, 19, 250-252.

33. Niederhofer $H$ : Welche Langzeitauswirkungen hat die pränatale Mutter-Kind-Bindung? Die Hebamme. 2006, 19, 29-33.

34. Rowe-Murray H., Fisher J.: Baby Friendly Hospital Practices: Cesarean section is a persistent barrier to early initiation of breastfeeding. Birth. 2002, 29 (2), 124-131.

35. Lang C.: Bonding. Bindung fördern in der Geburtshilfe. Elsevier, Urban \& Fischer Verlag, München 2009.

36. Moehler E.: Maternal depressive symptoms in the postnatal period are associated with long-term impairment of mother-child bonding. Arch Womens Ment Health. 2006, 9 (5), 273-278.

37. Rocha S.M.: Mother-child bonding: comparative study of mothers after normal delivery and cesarean section. Rev Bras Enferm. 2003, 56 (2), 125-129. 